\title{
Profile of patients treated with malariotherapy in a psychiatric hospital in Porto Alegre, Brazil: a historical note
}

\author{
Perfil dos pacientes tratados com malarioterapia em hospital psiquiátrico \\ de Porto Alegre: nota histórica
}

Guilherme Astor Torres, ${ }^{1}$ Maria Helena Itaqui Lopes, ${ }^{2}$ Edson Medeiros Cheuiche, ${ }^{3}$ Luiz Gustavo Guilhermano

\begin{abstract}
Introduction: Malariotherapy was a treatment to cure neurosyphilis developed in 1917 by Wagner-Jauregg, by inoculating blood infected with malaria in patients with neurosyphilis. The patient had febrile episodes that often cured him of the syphilitic infection. This treatment won the Nobel Prize in Medicine in 1927 and it was introduced in Hospital Psiquiátrico São Pedro (HPSP) in 1929.

Methods: This is a descriptive retrospective cross-sectional study with collection of historical secondary data. Data were collected from a sample of 19 medical records of patients treated with malariotherapy in HPSP, in 1929 and 1930.

Results: Most patients were white men aged from 25 to 40 years. The mean length of hospital stay was 1.4 year and the outcomes at this early application of malariotherapy were mostly negative $(63.2 \%$ died).

Discussion: The 19 cases evaluated in this study refer to the first year of application of malariotherapy in HPSP. The statistics available on the total number of dead and cured people over the 10 years this therapy was deployed suggest that the outcomes were better in the subsequent years, possibly due to improvement of technique. As a consequence of this innovative research, which had as its principle reorganizing the central nervous system by using the seizure triggered by malaria fever, other forms of shock therapies were developed, such as insulin therapy, cardiazol shock therapy, and electroconvulsive therapy. Keywords: Neurosyphilis, malaria fever therapy, Wagner-Jauregg.
\end{abstract}

\section{Resumo}

Introdução: A malarioterapia foi um tratamento para a cura da neurossífilis desenvolvido em 1917 por Wagner-Jauregg, através da inoculação de sangue contaminado pela malária em pacientes com neurossífilis. O paciente apresentava episódios febris que, muitas vezes, curavam-no da infecção sifilítica. Esse tratamento recebeu o Prêmio Nobel de Medicina em 1927 e foi introduzido no Hospital Psiquiátrico São Pedro (HPSP) em 1929.

Métodos: Este é um estudo transversal retrospectivo descritivo com coleta de dados secundários históricos. Foram coletados dados de uma amostra de 19 prontuários médicos de pacientes tratados com malarioterapia no HPSP, em 1929 e 1930.

Resultados: A maioria dos pacientes eram homens brancos com idades entre 25 e 40 anos. O tempo médio de internação foi de 1,4 ano e os desfechos nesse início de aplicação da malarioterapia foram majoritariamente negativos (63,2\% foram a óbito).

Discussão: Os 19 casos avaliados neste estudo referem-se ao primeiro ano de aplicação da malarioterapia no HPSP. As estatísticas existentes sobre o total de curados e mortos ao longo dos 10 anos de implantação dessa terapêutica sugerem que os desfechos dos anos seguintes foram melhores, possivelmente pelo aprimoramento da técnica. Como consequência dessa pesquisa inovadora, que tinha como princípio reorganizar o sistema nervoso central por meio da convulsão desencadeada pela febre da malária, outras formas de terapias de choque foram desenvolvidas, tais como a insulinoterapia, o choque por cardiazol e a eletroconvulsoterapia.

Descritores: Neurossífilis, terapia com febre malárica, WagnerJauregg.

\footnotetext{
${ }^{1}$ Lato sensu degree in Psychiatry, Hospital São Lucas da PUCRS, Porto Alegre, RS, Brazil. ${ }^{2}$ PhD in Clinical Medicine. Vice President, Associação Gaúcha de História da Medicina (AGHM), Porto Alegre, RS, Brazil. ${ }^{3}$ Historian, Cultural Memory Service, Hospital Psiquiátrico São Pedro (HPSP), Porto Alegre, RS, Brazil. ${ }^{4}$ Assistant professor, Department of Internal Medicine, School of Medicine, Pontifícia Universidade do Rio Grande do Sul (PUCRS), Porto Alegre, RS, Brazil. President, AGHM, Porto Alegre, RS, Brazil.

Financial support: none.

Submitted Dec 15 2013, accepted for publication May 21 2014. No conflicts of interest declared concerning the publication of this article.

Suggested citation: Torres GA, Lopes MHI, Cheuiche EM, Guilhermano LG. Profile of patients treated with malariotherapy in a psychiatric hospital in Porto Alegre, Brazil: a historical note. Trends Psychiatry Psychother. 2014;36(3):169-172. http://dx.doi.org/10.1590/2237-6089-2013-0063
} 


\section{Introduction}

The most curious page in the history of psychiatry is malariotherapy, which won the only Nobel Prize in Medicine for psychiatry until 2000. Its creator, Julius Wagner-Jauregg, still remains as the only psychiatrist who received the Nobel Prize for research in Mental Health. ${ }^{1-3}$ Malariotherapy was essential to provide psychiatry with the status of medical specialty, since, for the first time, it was possible to relate therapeutic practice to some illness and achieve a positive outcome. ${ }^{2}$ It is worth recalling an aphorism by Osler (1902): "The philosophies of an era become the absurdities of the next era," because this treatment, so important and prized at a certain time, became obsolete in a few decades. ${ }^{1}$ By the early 20th century, there was no specific treatment for syphilis and the causative agent of this disease was not even known. Soon after the discovery of its etiologic agent, the bacterium Treponema pallidum, ${ }^{4-7}$ Erlich (1910) developed the first effective treatment to fight it, arsphenamine. However, it treated only the primary and secondary stages of the disease, but did not act on the tertiary stage, i.e. neurosyphilis. In the latter, T. pallidum has reached the brain of patients, causing dementia and progressive general paralysis, which led to neuropsychomotor deterioration and death. ${ }^{4-6}$ The disease reached $20 \%$ of patients in psychiatric asylums. ${ }^{6}$

According to Rimbaud, progressive general paralysis is a diffuse meningoencephalitis having a syphilitic nature, with mental and neurological manifestations formed by delusional disorders and a condition of intellectual deficit, by paralytic and convulsive motor accidents with progressive evolution, which lead to dementia, psychic decay, and death. ${ }^{8}$

In Austria, the physician and researcher Julius Wagner-Jauregg had observed that some neurosyphilitic patients improved after undergoing intense fever. Then, he started experimenting with ways to cause controllable and reversible high fever. After many trials over several years, he observed that the best results were obtained by injecting blood contaminated with Plasmodium vivax, the etiologic agent of malaria, 1-4 cc subcutaneously, thus producing the desired tertian fever in neurosyphilitic patients and controlling malaria with quinine. ${ }^{1-6}$

In 1917, nine patients with neurosyphilis were treated with Jauregg with malariotherapy and 6 of them had extensive remission. Once the outcomes were reported, soon the treatment was widely used worldwide. ${ }^{5,9}$ Even with a high percentage of lethality, the outcomes were considered satisfactory for the time, given the lack of treatment options for patients with neurosyphilis; among them, death reached $87 \% .^{5}$ The importance of malariotherapy led the Swedish Academy of Sciences to award the Nobel Prize in Medicine to Wagner-Jauregg, in 1927.
In 1929, this treatment was brought to Hospital Psiquiátrico São Pedro (HPSP), in Porto Alegre, Brazil, by Jacintho Godoy, in collaboration with the parasitologist Raul Di Primio. The treatment was applied to 454 people ${ }^{10}$ until 1939.1,10 Since 1943, when Mahoney used it, penicillin became the treatment of choice, because it fought $T$. pallidum in an effective way in the central nervous system. ${ }^{7}$

\section{Method}

The study had a descriptive retrospective crosssectional design, with collection and analysis of historical secondary data from medical records of patients treated with malariotherapy in HPSP, currently available in Arquivo Público do Rio Grande do Sul (APERS), and it was approved by the Research Ethics Committee of HPSP. This study collected data pre-set by a pilot sample of 19 medical records of the early period of deployment of malariotherapy in HPSP, corresponding to the first year this therapy was used, with a total of 454 medical records of patients undergoing this treatment between 1929 and 1939. The inclusion criteria of this study was patient who underwent malariotherapy within the period described in the hospital under analysis, and there was no exclusion criterion.

\section{Results}

The cases examined involved patients hospitalized between 1929 and 1930 (21.2 and 78.9\%, respectively). Out of these, most were white men and more than half were between 25 and 40 years old at the time of admission.

Many patients were hospitalized due to syphilis $(31.6 \%)$. About $1 / 3$ of the medical records did not contain this information at the time of admission, though most came showing behavioral changes. Symptoms of depression were observed, such as: sadness, weakness, discouragement, isolation, and suicidal thoughts, while others had ideas of grandeur and megalomania. Others had agitation and aggressiveness. Subsequently, the diagnoses were established as paralytic dementia $(47.4 \%)$, general paralysis $(47.4 \%)$, and cerebral syphilis with a schizophrenic nature (5.3\%). Most patients had no history of mental illnesses, none had been previously hospitalized in a psychiatric hospital, and only a minority $(10.5 \%)$ had family history of mental illnesses. The only chemical substances whose use was reported were alcohol and tobacco. Thirty-six percent of patients had had another venereal disease, terminology used at the time to designate sexually transmitted diseases. Most cases were gonorrhea (common bacterial infection, caused by Neisseria 
gonorrhoeae, a gram-negative diplococcus transmitted almost exclusively by sexual or perinatal contact ${ }^{11}$ ).

Medical records also contained information regarding patients' behavior and personality. Several characteristics were mentioned, and Introspective personality (47.4\%), violent-angry-impulsive behavior (36.8\%), and jealous and close-fisted ways (31.6\%) stood out.

The mean length of hospital stay was 1.4 year and the outcomes were mostly negative. Only 3 patients were discharged after cure, 4 were assigned to undergo home care, while 12 died. Table 1 shows the demographic data of patients evaluated.

Table 1 - Demographic data of patients evaluated

\begin{tabular}{|c|c|c|}
\hline & N (\%) & (Mean, SD) \\
\hline Age & & $36.16 \pm 9.34$ \\
\hline$>25$ years & $2(10.5)$ & \\
\hline 25 to 40 years & $11(57.9)$ & \\
\hline 41 to 55 years & $6(31.6)$ & \\
\hline$<55$ years & $0(0.0)$ & \\
\hline \multicolumn{3}{|l|}{ Gender } \\
\hline Male & $17(89.5)$ & \\
\hline \multicolumn{3}{|l|}{ Race } \\
\hline White & $17(89.5)$ & \\
\hline Black & $1(5.3)$ & \\
\hline Mixed & $1(5.3)$ & \\
\hline \multicolumn{3}{|l|}{ Marital status } \\
\hline Single & $11(57.9)$ & \\
\hline Married & $7(36.8)$ & \\
\hline No data & $1(5.3)$ & \\
\hline \multicolumn{3}{|l|}{ Educational level } \\
\hline Primary education incomplete & $4(21.0)$ & \\
\hline Primary education complete & $3(15.8)$ & \\
\hline Secondary education incomplete & $3(15.8)$ & \\
\hline Did not attend school & $3(15.8)$ & \\
\hline No data & $6(31.6)$ & \\
\hline \multicolumn{3}{|l|}{ Birthplace } \\
\hline Porto Alegre & $8(42.1)$ & \\
\hline $\begin{array}{l}\text { Countryside of Rio Grande do } \\
\text { Sul }\end{array}$ & $11(57.9)$ & \\
\hline \multicolumn{3}{|l|}{ Admission diagnosis } \\
\hline Paralytic dementia & $9(47.4)$ & \\
\hline General paralysis & $9(47.4)$ & \\
\hline $\begin{array}{l}\text { Cerebral syphilis with a } \\
\text { schizophrenic nature }\end{array}$ & $1(5.3)$ & \\
\hline \multicolumn{3}{|l|}{ Medical history } \\
\hline Mental illness in the family & $2(10.5)$ & \\
\hline Diseases in adulthood & $4(21.0)$ & \\
\hline Other venereal diseases & $7(36.8)$ & \\
\hline Previous mental disorders & $0(0.0)$ & \\
\hline Use of toxic substances & $8(42.1)$ & \\
\hline \multicolumn{3}{|l|}{ Number of hospitalizations } \\
\hline Length of hospital stay & & $1.4 \pm 1.6$ \\
\hline \multicolumn{3}{|l|}{ Reason for hospital discharge } \\
\hline Home care & $4(21.1)$ & \\
\hline Cured & $3(15.8)$ & \\
\hline Dead & $12(63.2)$ & \\
\hline
\end{tabular}

\section{Discussion}

We emphasize that the 19 cases evaluated in this study refer to the first year of deployment of malariotherapy in HPSP. The statistics available on the total number of dead and cured people over the 10 years this therapy was deployed ${ }^{9}$ suggest that the outcomes were better in the subsequent years, possibly due to improvement of technique. Reinforcing this hypothesis, the homage expressed in a bronze plaque at the hall of HPSP states: "To Wagner-Jauregg, from those who came back to their families and society through malariotherapy" (Jan 31 1929 to Jan 31 1939). ${ }^{1}$

According to Louzada, ${ }^{10}$ in an unpublished paper on the statistics of all 454 cases treated through malariotherapy in HPSP from 1929 to 1939, there were 215 "hospital discharges due to death" and 239 "hospital discharges due to cure," i.e., $47.3 \%$ of patients died. Although this is a high figure, it is not as significant as the 12 deaths out of 19 cases identified in our sample for 1929 . As these 19 cases under study refer to the first year technique was deployed in HPSP, it is possible that the team improved it by means of practice and the best results came in subsequent years. ${ }^{10}$

Due to the sexual transmissibility of syphilis and having in mind the fact its manifestation takes place at the tertiary stage about 10 years after the first infection, it is not a matter of surprise that most patients (57.9\%) were between 25 and 40 years of age. Because of cultural differences regarding gender in the early 20th century, which allowed greater freedom of behavior to males, it was not astonishing that $89.5 \%$ of patients were men. The same high figure was found for white patients, something which may be explained by the fact this study was conducted in southern Brazil, where a similar proportion of inhabitants is of European descent, unlike the northern and northeastern regions of the country. The predominance of single individuals (57.9\%) may stem from the fact they were living in a situation with less sexual safety and more promiscuity. Most patients $(57.9 \%)$ were from the countryside of the state, because HPSP is a statewide referral hospital and the countryside of Rio Grande do Sul has a larger population than the capital city. There is no record on the educational level of most patients $(31.6 \%)$, which made it difficult to interpret data based on the current system.

Regarding diagnosis, $100 \%$ of patients have already been admitted with diagnoses related to tertiary syphilis. Only $10.5 \%$ of patients had a family history of mental illness, something which is expected due to the infectious nature of neurosyphilis, unlike other psychiatric diseases such as schizophrenia or bipolar affective disorder, which has a genetic influence in the 
etiology. In turn, the use of "toxic substances" (alcohol and tobacco) is reported for most patients (42.1\%), possibly due to greater negligence regarding sexual safety among these people. This is reinforced by the second highest percentage of $36.8 \%$ of patients with other venereal diseases. The fact that we identified $63.2 \%$ of hospital discharges due to death reveals not only the severe clinical conditions of patients with neurosyphilis, but also the potential lethality of malariotherapy. This mortality, although high (63.2\%), represented an improvement when compared to the natural outcome of this disease ( $87 \%$ of mortality). ${ }^{5}$

This study measures the historical importance of malariotherapy in the local and global context. Within the socio-scientific conjuncture of the time, we observe an innovative treatment, worthy of receiving a Nobel Prize. This therapeutic procedure, even today, could be considered unthinkable, in face of the current technology and social context. Data show that multiple variables could be resumed from the original medical records, revealing the demographic, clinical and pathological, and psychiatric profile of patients, including valuable information related to personality and mood. This evidence may have significant potential for further studies, which, like this, can point out new treatment options for diseases still with no prospect of cure. Relying on a larger sample, it could be possible to cross variables and look for associations. This pilot study provides an introduction to knowledge on malariotherapy and the history of psychiatric therapies. The fact that malariotherapy has taken psychiatry to a new perspective is of paramount historical importance, by claiming it is a medical specialty, because people started relating therapeutic intervention to an illness, something which did not happen so far. As a consequence of this model, other forms of psychiatric therapy were developed, by using the same principle. Malariotherapy has inaugurated the era of biological treatments, legitimizing psychiatry as a medical practice. The recognition of this medical practice involves the sequence of logical reasoning that starts by knowing the natural history of some illness, the diagnostic methods, the etiology, the etiologic agent, and the specific treatment. Deriving from this innovative intervention, i.e. malariotherapy, shock treatments emerged, such as insulin therapy, cardiazol shock therapy, and electroconvulsive therapy. ${ }^{12,13}$

\section{Acknowledgments}

To professor Rita Mattiello, for her precious help in epidemiology and biostatistics, and to the MSc biologist Letícia Dadalt, for her invaluable collaboration in biostatistics and in developing the final version of this piece of writing.

\section{References}

1. Mattos SG, Cury JA. A malarioterapia no tratamento da neurossífilis. In: Guilhermano LG, Schwartsmann, LCB, Serres JP, Lopes MHI, organizadores. Páginas da história da medicina. Porto Alegre: EDIPUCRS; 2010. Parte II, p. 151-60.

2. Tarelow GQ. Um tratamento de choque: a aplicação da malarioterapia no Hospital do Juquery (1925-1940). Cad Hist Cienc Inst Butantan. 2009;5:7-22.

3. Howes OD, Khambhaita A, Fusar-Poli P. Julius Wagner-Jauregg, 1857-1940. Am J Psychiatry. 2009;166:409.

4. Kragh JV. Malaria fever therapy for general paralysis of the insane in Denmark. Hist Psychiatry. 2010;21:471-86.

5. Kaplan RM. Syphilis, sex and psychiatry, 1789-1925: Part 2. Australas Psychiatry. 2010;18:22-7.

6. Austin SC, Stolley PD, Lasky T. The history of malariotherapy for neurosyphilis. Modern parallels. JAMA. 1992;268:516-9.

7. Gastal FL, Leite SSO, Andreoli SB, Gameiro MA, Gastal CL, Gazalle FK, et al. Tratamento etiológico em psiquiatria: o modelo da neurossífilis. Rev Bras Psiquiatr. 1999;21:29-35.

8. Litter $M$, Wexselblatt $M$. Sífilis e paralisis general progresiva. Tratado de Neurologia. 5a ed. Buenos Aires: El Ateneo; 1952. p. 773-92.

9. Wagner-Jauregg J. The treatment of general paresis by inoculation of malaria. J Nerv Ment Dis, 1922;55:369-75.

10. Louzada P. Estudo estatístico da malarioterapia. Porto Alegre: Hospital Psiquiátrico São Pedro; 1939.

11. Penna GO, Hajjar LA, Braz TM. Gonorréia. Rev Soc Bras Med Trop. 2000;33:451-64.

12. Tarelow GQ. Um tratamento de choque: a aplicação da malarioterpia no Hospital do Juquery (1925-1940). Cad Hist Cienc Inst Butantan. 2009;5:7-22.

13. Gottschall CAM. Sistemas de medicina. In: Lopes MHI, Guilhermano LG, Schwarstmann LCB, organizadores. Encontros com a história da medicina. Porto Alegre: Luminara; 2013. Parte III, p. 335-63

\section{Correspondence:}

Luiz Gustavo Guilhermano

Rua Comendador Caminha, 312/204, Moinhos de Vento

90430-030 - Porto Alegre, RS - Brazil

Tel./Fax: +55 (51) 3346.5610

E-mail: gumano@terra.com.br 